\title{
Investigation of the Erosive Potential of Different Types of Alcoholic Beverages
}

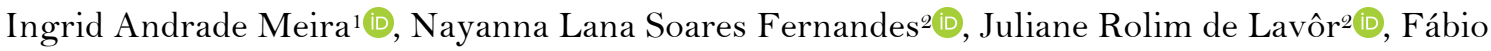 \\ Correia Sampaio $^{2}$, Andressa Feitosa Bezerra de Oliveira ${ }^{3}$
}

\footnotetext{
1Department of Prosthodontics and Periodontology, Piracicaba Dental School, University of Campinas, Piracicaba, SP, Brazil.

${ }^{2}$ Department of Clinical and Social Dentistry, School of Dentistry, Federal University of Paraíba, João Pessoa, PB, Brazil.

${ }^{3}$ Department of Morphology, School of Dentistry, Federal University of Paraíba, João Pessoa, PB, Brazil.
}

Author to whom correspondence should be addressed: Ingrid Andrade Meira, Avenida Limeira, 901, Areião, Piracicaba, SP, Brazil. 13414-903. Phone: +55 83 99909-8804. E-mail: ingrid_meiraa@hotmail.com.

Academic Editors: Alessandro Leite Cavalcanti and Wilton Wilney Nascimento Padilha

Received: 18 May 2019 / Accepted: 21 February 2020 / Published: 19 March 2020

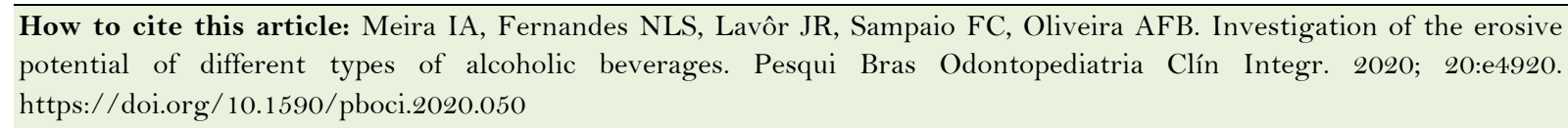

\begin{abstract}
Objective: To evaluate the erosive potential of different alcoholic beverages according to $\mathrm{pH}$, titratable acidity and buffering capacity. Material and Methods: Thirteen industrialized alcoholic beverages of different brands were selected and divided into five groups according to their type and composition. The $\mathrm{pH}$ measurement and titratable acidity for $\mathrm{pH} 5.5$ and 7.0 were performed in triplicate in $50 \mathrm{~mL}$ of each beverage. The buffering capacity was calculated based on $\mathrm{pH}$ and titratable acidity for $\mathrm{pH}$ 7.0. ANOVA, Tukey, and Pearson correlation, with $\mathrm{p}<0.05$, were used for data analysis. Results: Data showed normal distribution by Shapiro-Wilk test. The $\mathrm{pH}$ of alcoholic beverages ranged from 2.49 (Miks Ice Tea - Green Fruits) to 7.64 (Smirnoff). The highest values of acid titration (4.68) and buffer capacity (19.97) were observed in Smirnoff Ice. The following correlations $(\mathrm{p}<0.01)$ were noted between: $\mathrm{pH}$ and titratable acidity; buffering capacity and $\mathrm{pH}$; buffering capacity and titratable acidity. Conclusion: Some beers and alcopops presented erosive potential due to their lower $\mathrm{pH}$ associated with high acid titration values. The whisky and sugarcane liquor examined were not potentially erosive.
\end{abstract}

Keywords: Alcoholic Beverages; Alcoholism; Adolescent; Tooth Erosion; Dental Enamel. 


\section{Introduction}

Dental erosion is defined as a loss of dental hard tissue without bacterial involvement [1,2]. It has a multifactorial etiology and is caused by frequent teeth exposure to an acidic environment [1,2]. Acids associated with dental erosion may be from the stomach, diet [2], or from some working environment atmospheres [3]. The acids present in diets, like drinks and foods, have been the focus of current students. Nowadays, a change is being noted in habits with a high consumption of acidic foods and drinks and their relation to the increase in dental erosion worldwide [4].

Alcoholic beverages are defined as drinks that have more than $2.8 \%$ ethanol in their composition [5], with some variations according to countries' regulations [6]. In Brazil, only beverages with more than $0.5 \%$ alcohol by volume are considered alcoholic [6]. The per capita consumption of alcohol in Brazil is approximately 8.7 liters, considerably higher than the 6.2-liter average for the rest of the world [6].

The main alcoholic beverage researched is wine [5,7-9] since its professional tasting is associated with a high risk of dental erosion, and its severity tends to increase with years of occupational exposure [7]. Beer is the second most-consumed alcoholic beverage in the world [6], and it is the most consumed in Brazil with an annual consumption rate of about 57 liters per person [10] followed by sugarcane liquor [6]. However, among young adults and teenagers, mainly females, there is a preference for alcopop due to its more pleasant flavor [11-13].

Although some studies evaluated the erosive potential of alcoholic beverages, they have been restricted to wines [5,8] and some flavors and brands of beers [14,15] and alcopops [16,17]. Therefore, it is necessary to analyze other alcoholic beverages, such as whiskey and sugarcane liquor, as well as beers and alcopops of other brands and flavors since different compositions can alter their erosive potential [14,15]. Thus, this study aims to analyze the erosive potential of five types of alcoholic beverages frequently consumed by Brazilian people using their initial pH value, titratable acidity (TA) and buffering capacity (BC). The null hypothesis states that there are no differences between the erosive potential of the analyzed alcoholic beverages.

\section{Material and Methods}

Selection of Beverages

Thirteen industrialized alcoholic beverages of different brands were selected from local markets, and divided into five groups, according to their type and composition as described in Table 1 . Beverages were stored according to manufacturers' instructions. Mineral water and a cola-based soft drink were used as negative and positive controls, respectively.

Table 1. Type and brand of the alcoholic beverages analyzed in this study.

\begin{tabular}{clc}
\hline $\begin{array}{c}\text { Type of } \\
\text { Beverage } \\
\text { (Flavor) }\end{array}$ & \multicolumn{1}{c}{ Composition } & $\begin{array}{c}\text { Lot } \\
\text { Manufacturer }\end{array}$ \\
\hline Beer (Pilsen) & $\begin{array}{l}\text { Water, malt, unmalted sorghum, carbohydrates, hops, } \\
\text { antioxidants: INS } 316 \text { and INS } 221 \text { and stabilizer INS }\end{array}$ & Skol / Ambev S.A. \\
& 405. Alcohol by volume: $4,7 \%$ & Not Informed \\
Beer (Pilsen) & Water, malt, unmalted sorghum, carbohydrates, hops, & Brahma / Ambev \\
& antioxidants: INS 316 and INS 221 and stabilizer INS & S.A. Not Informed \\
& 405. Alcohol by volume: $5 \%$ & Antarctica / \\
Beer (Pilsen) & Water, malt, unmalted sorghum, carbohydrates, hops, & Ambev S.A. \\
& antioxidants: INS 316 and INS 221 and stabilizer INS & Not Informed
\end{tabular}


Beer Water, Pure Barley Malt, Hops, Yeast and Gluten. (Lager Premium) Alcohol by volume: 5\%

Alcopop Water and rectified alcohol. Alcohol by volume: $37.5 \%$

Alcopop Carbonated water, vodka, sugar, acidulants: citric acid (Lemon) and tartaric acid, natural lemon flavorings, acidity regulators: sodium citrate and malic acid and preservative sodium benzoate. Gluten-free. Alcohol by volume: $5 \%$

Alcopop Water, sugar, simple alcoholic distillate of cereals, (Lemon) acidulants: INS 330 and INS 334, natural lemon flavor, INS 150C dye and acidity regulators: INS 331III and INS 296. Gluten-free. Alcohol by volume: $8 \%$

Alcopop Vodka, sugar, preservative sodium benzoate (INS 211), (Green fruits acidulants: citric acid (INS 330), malic acid (INS 296) and with green tea) tartaric acid (INS 334), pear extract, kiwifruit extract, green tea extract, aroma identical to natural pear, INS 133 and INS 102 dyes, and carbonated water. Alcohol by volume: $5.5 \%$

Alcopop Vodka, sugar, preservative sodium benzoate (INS 211), (Green apple acidulants: citric acid (INS 330), tartaric acid (INS 334), with mate and EDTA sequestrant (INS 385), malic acid (INS 296), tonic water) green mate extract, aroma identical to natural apple green, aroma identical to natural tonic water and carbonated water. Alcohol by volume: $5.5 \%$

Red Wine Fermented grapes and sugar. Preservatives INS 202 and (Soft Burgundy) INS 220. Alcohol by volume: 10.1\%

Whisky Malt whisky, grain whisky distilled and aged in the (Scotch) origin, water and caramel dye INS $150^{\mathrm{a}}$. Alcoholic graduation $40 \%$ of the volume.

Sugarcane Distillation of fermented sugarcane juice and sugar Liquor Alcohol by volume: $40 \%$

Sugarcane Distillation of fermented sugarcane juice, sugar and Liquor water. Alcohol by volume: $39 \%$

Mineral Water Strontium: 0.027. Calcium: 0.614. Potassium: 0.500. Sodium: 94.100. Vanadium: 0.087. Sulfate: 39.26. Carbonate: 79.82. Bicarbonate: 33.77. Fluoride: 0.45. Nitrate: 0.31. Chloride: 2.83. Bromide: 0.02.

Cola-based Soft Carbonated water, sugar, kola nut extract, caramel Drink colorant IV, phosphoric acid as the acidifier, caffeine and natural aroma.

$\begin{array}{cc}\text { Heineken / CKBR } & 5202076 \mathrm{~B} 1451 \\ \text { S.A. } & \text { Not Informed } \\ \text { Vodka } & \\ \text { SMIRNOFF No.21 } & \\ \text { / DIAGEO } & \text { LE } 462 \text { L2 } \\ \text { Smirnoff Ice / } & \\ \text { DIAGEO } & \end{array}$

Skol Beats Senses / Not Informed Ambev S.A.

Miks Ice Tea /

Not Informed

Distribuidora de

Bebidas F Antônio

Chiamulera Ltda

Miks Ice Tea /

Not Informed

Distribuidora de

Bebidas F. Antônio

Chiamulera Ltda

Quinta do

O8 15 13:54 L3

Morgado / Fante

Ind. Bebidas Ltda

Teacher's /

15147R345001057

Pernord Ricard

Brasil Ind. e Com. Ltda

Pitú /

Pitú Ltda

51 Pirassununga /

Companhia Müller

de Bebidas

Nordeste

Ibira / Ibira Água

Mineral Natural

Ltda

Coca-Cola /

The Coca-Cola

Company

Analysis of pH, Titratable Acidity (TA), and Buffering Capacity ( $\beta$ )

For chemical analyses, $50 \mathrm{~mL}$ of each beverage at room temperature $\left(27^{\circ} \mathrm{C}\right)$ was used to measure the initial $\mathrm{pH}$ and titratable acidity for $\mathrm{pH}$ levels 5.5 and 7.0 (total amount of base needed to raise the $\mathrm{pH}$ of the substance to 5.5 or 7.0). The beverages $\mathrm{pH}$ levels were measured immediately after opening it using a calibrated electrode coupled to a pH meter (Orion, model 420A, Thermo Fischer Science Inc., Waltham, MA). After this, the freshly-opened alcoholic beverage was placed in a beaker with a non-heating magnetic stirrer until a stable reading was obtained.

The TA was estimated with the addition of increments of $0.2 \mathrm{~mL}$ of $1 \mathrm{M}$ of standard $\mathrm{NaOH}$ solution, until $\mathrm{pH}$ reached 5.5 and 7.0, at room temperature $\left(27^{\circ} \mathrm{C}\right)$. Finally, the buffering capacity $(\beta)$ was calculated with the values of $\mathrm{pH}$ and quantity of $\mathrm{NaOH}$ added to the solution, using the formula proposed [18]: $\beta=\Delta \mathrm{C} \quad \Delta \mathrm{pH}$, which $\Delta \mathrm{C}$ is the amount of base used and $\Delta \mathrm{pH}$ is the change in $\mathrm{pH}$ caused by the addition of the base. All measurements for $\mathrm{pH}$, TA and $\beta$ were carried out in triplicate and an average result was obtained for each beverage. 
Statistical Analysis

Results were evaluated throughout descriptive and inferential analyses. The Shapiro-Wilk test was used to identify if the data had normal distribution. ANOVA, followed by Tukey test was used to compare the $\mathrm{pH}$, TA and $\beta$ between the tested groups. Pearson correlations were used to assess bivariate associations between the different chemical properties. The statistical calculations were performed using the SPSS 19 software. The significance level was set at 0.05 .

\section{Results}

The data had a normal distribution by the Shapiro-Wilk ( $p>0.05)$ test, allowing the use of parametric tests. A statistically significant relationship was observed between the groups analyzed (ANOVA, p<0.05): initial $\mathrm{pH}(\mathrm{F}=1463.991 ; \mathrm{df}=14 ; \mathrm{p}<0.001)$, titratable acidity for $\mathrm{pH} 5.5(\mathrm{~F}=201.109 ; \mathrm{df}=12 ; \mathrm{p}<0.001)$, titratable acidity for $\mathrm{pH} 7.0(\mathrm{~F}=201.218 ; \mathrm{df}=12 ; \mathrm{p}<0.001)$ and buffering capacity $(\mathrm{F}=153.780 ; \mathrm{df}=12$; $\mathrm{p}<0.001)$.

Among the alcoholic beverages evaluated, it was noted that the lowest $2.49 \mathrm{pH}$ was from Miks Ice Tea (Green Fruits), while the highest 7.64 was from the Smirnoff Red Triple. Furthermore, it was observed that the highest value of titratable acidity and buffering capacity were found on alcopop (Smirnoff Ice) and for both variables, the lowest values were obtained from Pitú (Table 2 ).

Table 2. The mean ( \pm DP) of initial pH, titratable acidity (mmol/1 NaOH to reach $\mathrm{pH} 5.5$ and 7.0$)$ and buffering capacity $(\beta)$ of each tested beverage.

\begin{tabular}{|c|c|c|c|c|c|}
\hline \multirow{2}{*}{ Group } & \multirow{2}{*}{ Beverages } & \multirow[t]{2}{*}{$\mathrm{pH}$} & \multicolumn{2}{|c|}{ TA } & \multirow[t]{2}{*}{$\boldsymbol{\beta}$} \\
\hline & & & $\mathrm{pH} 5.5$ & $\mathrm{pH} 7.0$ & \\
\hline \multirow[t]{5}{*}{ Beer } & Skol & $4.05 \pm 0.05$ & $0.57 \pm 0.29$ & $1.87 \pm 0.15$ & $12.20 \pm 0.81$ \\
\hline & Skol Beats & $2.51 \pm 0.05$ & $2.87 \pm 0.15$ & $4.55 \pm 0.05$ & $18.59 \pm 0.36$ \\
\hline & Brahma & $4.11 \pm 0.01$ & $0.57 \pm 0.03$ & $2.05 \pm 0.13$ & $13.64 \pm 0.88$ \\
\hline & Antarctica & $3.85 \pm 0.05$ & $0.63 \pm 0.03$ & $2.08 \pm 0.16$ & $12.7 \pm 0.88$ \\
\hline & Heineken & $4.26 \pm 0.03$ & $0.60 \pm 0.05$ & $2.10 \pm 0.22$ & $14.69 \pm 1.58$ \\
\hline \multirow[t]{2}{*}{ Sugarcane Liquor } & Pitú & $4.29 \pm 0.02$ & $0.02 \pm 0.00$ & $0.03 \pm 0.00$ & $0.22 \pm 0.00$ \\
\hline & 51 & $4.01 \pm 0.08$ & $0.04 \pm 0.00$ & $0.06 \pm 0.01$ & $0.38 \pm 0.05$ \\
\hline \multirow[t]{4}{*}{ Alcopop } & Smirnoff Red Triple & $7.64 \pm 0.35$ & $0.00 \pm 0.00$ & $0.00 \pm 0.00$ & $0.00 \pm 0.00$ \\
\hline & Smirnoff Ice & $2.70 \pm 0.10$ & $3.22 \pm 0.13$ & $4.68 \pm 0.13$ & $19.97 \pm 0.17$ \\
\hline & Miks Ice Tea (Green Fruits) & $2.49 \pm 0.03$ & $2.67 \pm 0.16$ & $4.10 \pm 0.13$ & $16.79 \pm 0.59$ \\
\hline & Miks Ice Tea (Green Apple) & $2.71 \pm 0.01$ & $2.15 \pm 0.05$ & $3.33 \pm 0.21$ & $14.57 \pm 0.83$ \\
\hline Red Wine & Quinta do Morgado & $3.12 \pm 0.01$ & $3.3 \pm 0.48$ & $3.87 \pm 0.55$ & $18.47 \pm 2.49$ \\
\hline Whisky & Teacher's & $3.80 \pm 0.03$ & $0.04 \pm 0.01$ & $0.06 \pm 0.01$ & $0.40 \pm 0.04$ \\
\hline \multirow[t]{2}{*}{ Controls } & Ibira & $10.11 \pm 0.02$ & $\mathrm{O}$ & $\mathrm{O}$ & $\mathrm{O}$ \\
\hline & Coca-Cola & $2.47 \pm 0.01$ & $0.63 \pm 0.15$ & $1.97 \pm 0.21$ & $8.36 \pm 0.86$ \\
\hline
\end{tabular}

Analyzing all the beverages, including the control groups, it was observed that the positive control had the lowest $\mathrm{pH}$ (2.47). However, this control did not have the highest titratable acidity and buffering capacity. Besides that, it was noted that all alcoholic beverages had a statistically different initial pH from negative and positive control, except for the Skol Beats and the Miks Ice Teas with green fruits or green apple (Table 3).

A significant correlation was observed between buffering capacity and initial $\mathrm{pH}(\mathrm{r}=-0.531, \mathrm{p}<0.01)$; and titratable acidity $(\mathrm{pH} 7.0)$ with buffering capacity $(\mathrm{r}=+0.947, \mathrm{p}<0.01)$ and initial $\mathrm{pH}(\mathrm{r}=-0.743, \mathrm{p}<0.001)$. 
Table 3. The average of the initial $\mathrm{pH}$ values of the alcoholic beverages evaluated in comparison to negative and positive controls.

\begin{tabular}{|c|c|c|c|c|c|c|}
\hline \multirow{3}{*}{ Groups } & \multirow{3}{*}{ Beverages } & \multicolumn{5}{|c|}{ pH Initial } \\
\hline & & \multicolumn{3}{|c|}{ Mineral Water } & \multirow{2}{*}{$\begin{array}{c}\text { Coke } \\
\text { Mean (DP) }\end{array}$} & \multirow[b]{2}{*}{ p-value } \\
\hline & & Mean (DP) & Mean (DP) & p-value & & \\
\hline \multirow[t]{5}{*}{ Beer } & Skol & $4.05 \pm 0.05$ & $10.11 \pm 0.02$ & 0.000 & $2.47 \pm 0.01$ & $<0.001$ \\
\hline & Skol Beats & $2.51 \pm 0.04$ & $10.11 \pm 0.02$ & 0.000 & $2.47 \pm 0.01$ & 1.000 \\
\hline & Brahma & $4.11 \pm 0.01$ & $10.11 \pm 0.02$ & 0.000 & $2.47 \pm 0.01$ & $<0.001$ \\
\hline & Antarctica & $3.85 \pm 0.04$ & $10.11 \pm 0.02$ & 0.000 & $2.47 \pm 0.01$ & $<0.001$ \\
\hline & Heineken & $4.26 \pm 0.02$ & $10.11 \pm 0.02$ & 0.000 & $2.47 \pm 0.01$ & $<0.001$ \\
\hline \multirow[t]{2}{*}{ Sugar Cane Liquor } & Pitú & $4.29 \pm 0.03$ & $10.11 \pm 0.02$ & 0.000 & $2.47 \pm 0.01$ & $<0.001$ \\
\hline & 51 & $4.01 \pm 0.07$ & $10.11 \pm 0.02$ & 0.000 & $2.47 \pm 0.01$ & $<0.001$ \\
\hline \multirow[t]{4}{*}{ Alcopop } & Smirnoff Red Triple & $7.64 \pm 0.35$ & $10.11 \pm 0.02$ & 0.000 & $2.47 \pm 0.01$ & $<0.001$ \\
\hline & Smirnoff Ice & $2.70 \pm 0.11$ & $10.11 \pm 0.02$ & 0.000 & $2.47 \pm 0.01$ & 0.039 \\
\hline & Miks (Green Fruits) & $2.49 \pm 0.02$ & $10.11 \pm 0.02$ & 0.000 & $2.47 \pm 0.01$ & 1.000 \\
\hline & Miks (Green Apple) & $2.71 \pm 0.01$ & $10.11 \pm 0.02$ & 0.000 & $2.47 \pm 0.01$ & 0.146 \\
\hline Red Wine & Quinta do Morgado & $3.12 \pm 0.01$ & $10.11 \pm 0.02$ & 0.000 & $2.47 \pm 0.01$ & $<0.001$ \\
\hline Whisky & Teacher's & $3.80 \pm 0.02$ & $10.11 \pm 0.02$ & 0.000 & $2.47 \pm 0.01$ & $<0.001$ \\
\hline
\end{tabular}

\section{Discussion}

Alcoholism has become a worrisome world problem [6]. In the Western Pacific and South-East Asia regions, the consumption of alcoholic beverages has increased considerably. In Brazil, since the 1960s, the annual consumption of alcohol for individuals aged 15 years or older has almost tripled [19]. According to the age range, Brazilians aged between 18-29 years represent the age range with the greatest proportion of consumption of alcoholic beverages [20]. Although some studies have evaluated the erosive potential of alcoholic beverages, these have been restricted to wines [5,8] and some flavors and brands of beers [14,15] and alcopops [16,17].

Dental erosion is the acid dissolution of dental hard tissues caused by multiple extrinsic or intrinsic factors [1,2]. Acids from gastro-esophageal reflux disease and vomiting represent the intrinsic factors and those from occupational exposure and diet correspond to the extrinsic factors [1]. In this thought, the excessive use and frequency of some types of alcoholic beverages can be associated with both factors of dental erosion due to its chemical properties and predisposition to cause vomiting. Therefore, the exaggerated and frequent consumption of alcohol is one of the factors related to dental erosion [14].

In the present study, all alcoholic beverages analyzed had an initial pH higher and statistically different from the positive control, except for the Skol Beats and the beverages of Miks brand. It can be observed that only whisky (Teacher's), the sugarcane liquors (Pitú and 51) and the beers (Skol, Brahma and Heineken) had titratable acidity for $\mathrm{pH} 5.5$ lower than Coke. The same view is noted for the titratable acidity reached to pH 7.0, except for Brahma and Heineken beers. Moreover, all the alcohol drinks had buffering capacity higher than the positive control, except Pitú, 51, Smirnoff Red Triple and Teacher's. It is important to emphasize that Smirnoff Red Triple had a pH higher than 7.0 and because of that there was no need to measure its titratable acidity and buffering capacity. Interestingly, the vast majority of the analyzed beverages had low $\mathrm{pH}$ values (varying from 2.49 to 7.64 ), which may lead to enamel tooth demineralization. In general, it can be concluded that all beverages evaluated were able to cause enamel tooth demineralization, only considering that $\mathrm{pH}$ values lower than 5.5 can erode tooth enamel. However, some studies have reported that only drinks with a pH lower than 4.0 can actually cause dental erosion [15]. Consequently, Skol, Brahma, Heineken, Pitú, 51 and 
Smirnoff Red Triple should not cause enamel erosion. Analyzing according to the type of alcoholic beverages, alcopop was the group that showed the lowest $\mathrm{pH}$ values, probably related with its composition.

Alcopops are constituted by a maximum of 5\% alcohol by volume, sugars, citric and malic acid [20] with a $\mathrm{pH}$ around $3[16,18]$, corroborating the values found in most of the alcopops analyzed. In contrast, the Smirnoff Red Triple had the highest value of initial pH (7.64) between all tested alcoholic beverages. The great pH difference between Smirnoff Ice and Smirnoff Red Triple is probably the composition. Smirnoff Ice is composed of citric and tartaric acids, sugar, flavoring and acid regulators, while Red Triple is only composed of water and alcohol. In a previous study, was noted that erosive potential is determined by the total acid content and/or the type of acid that mostly composes beverages [17]. In addition, an in vitro study demonstrated that alcopops had a significant erosive effect on bovine enamel similar to the orange juice [16]. Finally, it is possible to note that the titratable acidity value for Smirnoff Ice was almost the double of the Coke, demonstrating the great difficulty that the saliva will have to buffer this beverage.

Regarding beers, the majority of them have a pH higher than 4.0, corroborating previous study [15]. Although, as the same trend alcopops, Skol Beats had a pH lower than 3.0, reflecting its composition with the addition of lemon juice. Furthermore, it can be observed that Heineken showed similar titratable acidity value for $\mathrm{pH} 5.5$ compared with other beers, even with the highest initial $\mathrm{pH}$ compared to the others. Thus, it demonstrates the difficulty of the Heineken group to buffer, agreeing with the data presented by other authors [14] in which the Heineken was the only beer that caused enamel surface loss by microhardness after 5 minutes exposure. It is speculated that pure barley malt is one of the reasons for Heineken's behavior [14]. The malted barley is fermented by yeasts and various organic acids (such as lactate, succinate and pyruvate) are excreted, including citrate [10]. This may explain its erosive power due to its ability to chelate the calcium present in dental enamel hydroxyapatite [22]. Therefore, it can be assumed that in the Heineken fermentation process, more citrate should be produced and, if this acid is not completely consumed during this process, the finished beer can present erosive properties [14]. The other beer analyzed had replacements (i.e., supplements) including part of the malted barley in its composition, reducing the citrate production. Therefore, according to beers types and brands [14,15], there are clear differences between their erosive potential, demonstrating the importance of erosive potential studies to analyze diverse beers.

The wine analyzed had a $\mathrm{pH}$ value lower than 4.0 with a high titratable acidity due probably to natural and organic acids present in its composition. The relation between wine-tasting professional and their higher risk of suffering erosion related to the great acid-tooth contact is already known [5,7]. On the other hand, sugarcane liquors (Pitú and 51) did not demonstrate erosive potential, having even a pH around 4.0, because of its very low acid titrations, presumably reflecting its composition based on alcohol, sugar and water. Finally, the whisky tested also showed an initial pH lower than 4.0, but both its acid titrations and buffering capacity were lower than Coke, demonstrating that the saliva will have no difficulty in buffering it.

Although the beverage's chemical characteristics such as $\mathrm{pH}$, titratable acidity and buffering capacity are important for the analysis of their erosive potential, the presence of acid components [1,3,5,22] and the concentration of calcium and phosphate $[1,14,15,18]$ can also perform a relevant role in their potential. Therefore, discussions about the beverage composition are one of the most relevant subjects in the dental erosion context [14]. In addition, some habits like smoking and the use of drugs are associated with alcohol consumption and may also cause dry mouth [23]. Associated with this, gastric problems, reflux episodes, and vomiting become frequent when there is high and frequent consumption of alcoholic beverages [24]. And all 
that can either contribute to enamel loss effect potentializing tooth-structure loss [21] and increasing the risk of dental erosion [23].

It is worth emphasizing that the present research has some limitations. It was analyzed only a few chemical properties of alcoholic beverages. Also, it was not used $\mathrm{pH}$ cycling and the presence of saliva and acquired film were not considered. They are important biological factors that influence and modulate the process of dental erosion [14,15,9]. However, this study is important to alert dentists, especially those attending teenagers, on the risks of dental erosion associated with alcohol consumption. Further, preventive advice can be given to teenagers and their parents, as avoiding brushing their teeth shortly after the consumption of acidic beverages and the importance of regular visits to the dentist [21]. Therefore, further studies should be carried out to evaluate other types and brands of alcoholic beverages, even as in vitro studies with $\mathrm{pH}$ cycling simulating erosive challenges and analysis of the enamel and dentin surface using profilometry.

\section{Conclusion}

The findings of this study indicate that some beers and alcopops may present dental erosive potential due to their lower $\mathrm{pH}$ associated with high acid titration and buffering capacity values. The whisky and sugarcane liquors examined were not potentially erosive.

\section{Authors' Contributions}

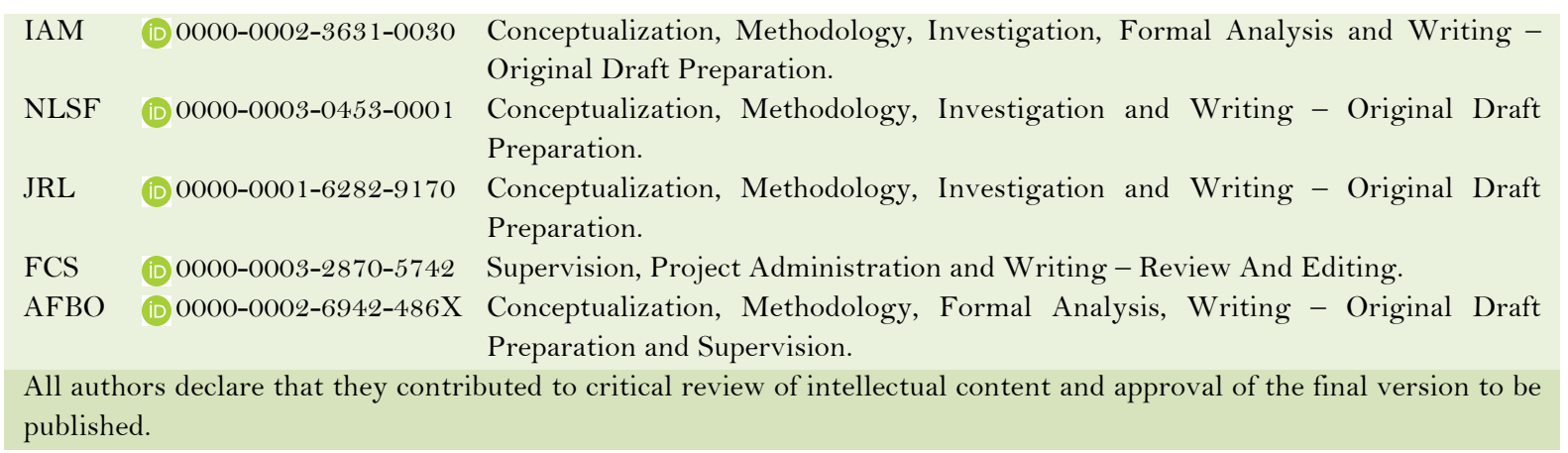

\section{Financial Support}

None.

\section{Conflict of Interest}

The authors declare no conflicts of interest.

\section{References}

[1] Lussi A, Schlueter N, Rakhmatullina E, Ganss C. Dental erosion - an overview with emphasis on chemical and histopathological aspects. Caries Res 2011; 45(S1):2-12. https://doi.org/10.1159/000325915

[2] Lussi A, Carvalho TS. Analyses of the erosive effect of dietary substances and medications on deciduous teeth. PLoS One 2015; 10(12):e0143957. https://doi.org/10.1371/journal.pone.0143957

[3] Zero DT. Etiology of dental erosion - extrinsic factors. Eur J Oral Sci 1996; 104(2):162-77. https://doi.org/10.1111/j.1600-0722.1996.tbo0065.x

[4] Schlueter N, Jaeggi T, Lussi A. Is dental erosion really a problem? Adv Dent Res 2012; 24(2):68-71. https://doi.org/10.1177/0022034512449836

[5] Meurman JH, Vesterinen M. Wine, alcohol, and oral health, with special emphasis on dental erosion. Quintessence Int 2000; 31(10):729-33. 
[6] World Health Organization. Global Status Report on Alcohol and Health. Geneve: WHO; 2014. Available from: https://www.who.int/substance_abuse/publications/global_alcohol_report/msbgsruprofiles.pdf. _ [Accessed on March 14, 2019].

[7] Wiktorsson A-M, Zimmerman M, Angmar-Månsson B. Erosive tooth wear: prevalence and severity in Swedish winetasters. Eur J Oral Sci 1997; 105(6):544-50. https://doi.org/10.1111/j.1600-0722.1997.tb00215.x

[8] Lupi-Peguriera L, Mullera M, Leforestierb E, Bertrandb MF, Bollac M. In vitro action of Bordeaux red wine on the microhardness of human dental enamel. Arch Oral Biol 2003; 48(2):141-5. https://doi.org/10.1016/s0003-9969(02)00206-6

[9] Brand HS, Tjoe Fat GM, Veerman EC. The effects of saliva on the erosive potential of three different wines. Aust Dent J 2009; 54(3):228-32. https://doi.org/10.1111/j.1834-7819.2009.01124.x

[10] Mardegan SF, Andrade TMB, de Sousa Neto ER, de Castro Vasconcellos EB, Martins LFB, Mendonça TG, et al. Stable carbon isotopic composition of Brazilian beers - a comparison between large- and small-scale breweries. J Food Compos Anal 2013; 29(1):52-7. https://doi.org/10.1016/j.jfca.2012.10.004

[11] Metzner C, Kraus L. The impact of alcopops on adolescent drinking: a literature review. Alcohol Alcohol 2008; 43(2):230-9. https://doi.org/10.1093/alcalc/agm 148

[12] Hughes ML, Rees JS. Alcopop induced erosion: management in general dental practice. Dent Update 2008; 35(5):32630. https://doi.org/10.12968/denu.2008.35.5.326

[13] Hibell B, Guttormsson U, Ahlström S, Balakireva O, Bjarnason T, Kokkevi A, et al. The 2011 ESPAD Report. Substance Use Among Students in 36 Countries. Available from: http://www.espad.org/sites/espad.org/files/The_2011_ESPAD_Report_FULL_2012_10_29.pdf. [Accessed on March 14, 2019].

[14] Zanatta RF, Esper MÂLR, Valera MC, Melo RM, Bresciani E. Harmful Effect of beer on bovine enamel microhardness - in vitro study. PLoS One 2016; 11 (10):e0163440. https://doi.org/10.1371/journal.pone.0163440

[15] Nogueira FN, Souza DN, Nicolau J. In vitro approach to evaluate potential harmful effects of beer on teeth. J Dent 2000; 28(4):271-6. https://doi.org/10.1016/S0300-5712(99)00072-X

[16] Ablal MA, Kaur JS, Cooper L, Jarad FD, Milosevic A, Higham SM, et al. The erosive potential of some alcopops using bovine enamel: an in vitro study. J Dent 2009; 37(11):835-9. https://doi.org/10.1016/j.jdent.2009.06.016

[17] Rees JS, Burford K, Loyn T. The erosive potential of the alcoholic lemonade Hooch. Eur J Prosthodont Restor Dent $1998 ; 6(4): 161-4$.

[18] Lussi A, Megert B, Peter Shellis R, Wang X. Analysis of the erosive effect of different dietary substances and medications. Br J Nutr 2012; 107(2):252-62. https://doi.org/10.1017/S0007114511002820

[19] Caetano R, Laranjeira R. A "perfect storm" in developing countries: economic growth and the alcohol industry. Addiction 2006; 101(2):149-52. https://doi.org/10.1111/j.1360-0443.2006.01334.x

[20] Caetano R, Mills B, Pinsky I, Zaleski M, Laranjeira R. The distribution of alcohol consumption and the prevention paradox in Brazil. Addiction 2012; 107(1):60-8. https://doi.org/10.1111/j.1360-0443.2011.03567.x

[21] Michel PA, Loing A, Manière MC. Alcopops: systemic and dental consequences. Arch Pediatr 2010; 17(12):1744-8. https://doi.org/10.1016/j.arcped.2010.08.002

[22] Lussi A, Jaeggi T. Dental Erosion: From Diagnosis to Therapy. Basel: Karger; 2006.

[23] Hamamoto D, Rhodus N. Methamphetamine abuse and dentistry. Oral Dis 2009; 15(1):27-37. https://doi.org/10.1111/j.1601-0825.2008.01459.x

[24] Holbrook WP, Furuholm J, Gudmundsson K, Theodórs A, Meurman JH. Gastric reflux is a significant causative factor of tooth erosion. J Dent Res 2009; 88(5):422-6. https://doi.org/10.1177/0022034509336530 